\title{
Determinants of health : theory, understanding, portrayal, policy
}

Citation for published version (APA):

Commers, M. J. (2001). Determinants of health : theory, understanding, portrayal, policy. [Doctoral Thesis, Maastricht University]. Universiteit Maastricht. https://doi.org/10.26481/dis.20010518mc

Document status and date:

Published: 01/01/2001

DOI:

10.26481/dis.20010518mc

Document Version:

Publisher's PDF, also known as Version of record

\section{Please check the document version of this publication:}

- A submitted manuscript is the version of the article upon submission and before peer-review. There can be important differences between the submitted version and the official published version of record. People interested in the research are advised to contact the author for the final version of the publication, or visit the DOI to the publisher's website.

- The final author version and the galley proof are versions of the publication after peer review.

- The final published version features the final layout of the paper including the volume, issue and page numbers.

Link to publication

\footnotetext{
General rights rights.

- You may freely distribute the URL identifying the publication in the public portal. please follow below link for the End User Agreement:

www.umlib.nl/taverne-license

Take down policy

If you believe that this document breaches copyright please contact us at:

repository@maastrichtuniversity.nl

providing details and we will investigate your claim.
}

Copyright and moral rights for the publications made accessible in the public portal are retained by the authors and/or other copyright owners and it is a condition of accessing publications that users recognise and abide by the legal requirements associated with these

- Users may download and print one copy of any publication from the public portal for the purpose of private study or research.

- You may not further distribute the material or use it for any profit-making activity or commercial gain

If the publication is distributed under the terms of Article $25 \mathrm{fa}$ of the Dutch Copyright Act, indicated by the "Taverne" license above, 


\section{SUMMARY}

The field of health promotion was founded on the pretense of "enabling individuals and communities to increase control over the determinants of health and thereby improve their health" (WHO/EURO, 1986). Maximizing people's power over the factors which affect their health is said to be morally responsible because it respects the autonomy of individuals and communities to decide for themselves which health goals they most wish to pursue and how to promote those goals in light of individual and community resources and values. Giving people power over the factors which affect their health has also been asserted as scientifically responsible. Experience has shown that people - alone or in cooperation with professionals - are capable of effecting positive changes in their environments and behavior in the interest of their own health which are far more substantial and lasting than the changes professionals could effect unilaterally.

Yet the ideal of enabling individuals and communities to "increase control over" the definition and determinants of their health is not synonymous with giving individuals and communities "complete control over" these matters. Of the limited extent to which we can establish control over the determinants of our health through conscious action, neither the public nor health professionals believe that the public should or could play an exclusive role. The general consensus is that we are all better served if the public's own important role in defining and promoting health is both facilitated and supplemented by the efforts of people who are trained to think about and act efficiently in the name of health. In other words, the public and health professionals must work together in some configuration to define health goals and the most appropriate means to achieve them. This dissertation was an attempt to ask to what extent the public does, should and could have a role in the structuring of health professionalism, as well as to provide some insight into why or why not the answers to these questions take the form they do.

Public policy is the domain in which health professionalism is given the overwhelming majority of its form. The purpose of this dissertation is to reflect upon how the public's understandings of health and health etiology are relevant to the structuring of health professionalism. Therefore, the dissertation is first and even foremost - necessarily concerned with the relevance of those understandings for public policy. Yet assessing the relevance of public understandings of health and health etiology for public policy requires both empirical documentation of those understandings. Such an assessment also demands the development of an explicit theoretical framework for conceptualizing the potential relevance of public understandings of health and health etiology for public policy and, hence, for the structuring of the ends and means embodied by health professional actions. This dissertation, therefore, begins by presenting such a theoretical framework. It then proceeds to empirical documentation of 
public understandings, and ends with reflections on the relevance of those understandings for public policy and the structuring of health professionalism.

Chapter 1 begins by asserting that empirical, theoretical, and practical insights have revealed limitations to positivist approaches in health professionalism. A working vocabulary is then developed for the discussion of subjectivity in relation to health and health professionalism. This vocabulary is employed in a deep reading of Aaron Antonovsky and René Dubos which leads to a model for grounding the abstraction of health in the concrete currency of health etiological resources. Finally, the work of Jürgen Habermas is used as a means of conceptualizing the dynamics of achieving consensus for action between professionals and public in regards to health-related ends and the means employed in pursuit of them.

Chapter 2 attempts to reveal a natural scientific foundation for the contention that participation is necessary for the optimization of health. A thermodynamic understanding of health and salutogenesis is discussed, and Antonovsky's salutogenic model is reformulated as a complexity model of health etiology. A wide body of salutogenic research is then used to demonstrate the link between the complexity model of health etiology and the need for participation. That link is found in that fact that the complexity model implies that many - if not most of the factors relevant to health status are either partially or exclusively accessible to those whose health is in question. This leads to a final section focusing on how professionals can support participation by researching and boosting people's understanding of health etiological factors as well as their power to influence them.

Chapters 3 and 4 present a qualitative study among 103 residents of Maastricht which assessed what the respondents believe determines their health. The main goal of the interviews was to generate the broadest possible inventory of what people believe to determine their health. Sub-goals were to assess whether response would differ to open and structured questions (to get an initial feeling for people's sensitivity) and whether signs of social variation existed in the data. Chapter 3 presents the aggregate inventory as well as an analysis of the response differences to open and structured questions. Chapter 4 provides an analysis of social variation in the findings by respondents' sex, age, average neighborhood income (a proxy for socioeconomic status) and smoking status. The work presented in Chapters 3 and 4 forms the basis for the quantitative study presented in Chapter 6.

Chapter 5 describes a content analysis of the five national Dutch newspapers with the largest daily circulations. The central objective of the content analysis was to characterize the portrayal of the determinants of health in the Dutch press. The press, used within this dissertation as a representative for the media in general, 
could comprise a critical means of communication between policy actors and the public. Yet much existing evidence indicates that the portrayal of determinants of health in the press is largely inconsistent with the messages which health professionals would wish to relate to the public. Further, evidence also suggests that the press does not often portray the public's understandings of the most appropriate ends and means for health professionalism nor does it support people in working independently of professionals to enhance their own health. The study detailed in this chapter tests these insights from previous research within the Dutch context and finds they are largely affirmed.

Chapter 6 presents a large-scale survey of the Dutch public in regards to what it understands as constituting and determining health. The goal of the large-scale survey was to provide a quantitative evaluation of the insights raised in Chapters 3 and 4 . Results of the survey were used to construct a LISREL model $(n=772)$ which relates the Dutch public's conceptions of salutogenic health etiology to conceptualizations of health itself and the amount of faith placed in differing types of professional health promotive strategies. These beliefs are also linked via the model to the sociodemographic characteristics of the sample respondents. Findings indicate that the Dutch public values a positive definition of health as much as a clinical definition, ascribe most importance to individually-influenceable determinants of health, and place more faith in medical care as a means to health than in public health strategies. The existence of social variation by gender, age, and smoking status in understandings of the determinants of health and professional strategies for health was strongly affirmed. In contrast, few differences of importance were found in such understandings among those of lower or higher socioeconomic status. Finally, respondents' agreement with each definition of health was associated in theoretically plausible ways with ascription of importance to different types of determinants of health. The findings in Chapter 6 are used as a basis for the study of policy content and its compatibility with the public understandings described in Chapter 7 .

Chapter 7 details an investigation of the implications of the compatibility of policy actors' and the public's assumptions regarding the most appropriate health-related ends and means for health professionalism. Documents influential within the development of primary prevention and health promotion policy in The Netherlands since 1985 were identified through a Delphi method and content analyzed to determine their portrayal of health and the determinants of health. The results of this content analysis were compared with the findings from Chapter 6. Finally, these comparisons were discussed with 17 persons who have relevant policy expertise to determine the meaning of the similarities and differences between policy actors' and public understandings of health and health etiology within the status quo and context of future health-related policy development. Findings of the content analysis and comparison of its results 
with the Chapter 6 survey indicated numerous similarities and differences between public and policy actors' assumptions. The public tended to discount those determinants less amenable to individual influence, including many social determinants of health. Policymakers gave such factors more - and perhaps more balanced - credence. Further, the interviews with policy experts revealed that the general public has modest but varied real and potential involvement in defining which issues are addressed by policies for health. On the other hand, the general public has a much more limited role in specifying the concrete shape those policies take in practice.

Chapter 8 summarizes the empirical findings presented in the dissertation in terms of the theory found in Chapters 1 and 2 and presents a nascent theory of public participation in the structuring of health professionalism via participation in public policy formulation. The empirical findings reveal that there are both opportunities for and barriers to the participation of public in the formulation of the health-related ends and means embodied by health professional activity. These opportunities and barriers are used to abstract a interculturally-generalizable theoretical framework for the extent to which public participation in the structuring of health professionalism via participation in public policy formulation is desirable and plausible. 


\section{SAMENVATTING}

Gezondheidsbevordering ("health promotion") vindt haar grondslag in het standpunt dat "mensen en gemeenschappen in staat worden gesteld de determinanten van hun gezondheid te beheersen en daardoor hun gezondheid verbeteren" (WHO/EURO, 1986). Men kan stellen dat de maximalisering van de beheersing door mensen van de factoren die hun gezondheid beïnvloeden moreel verantwoord is omdat dat de autonomie van het individu en de gemeenschap respecteert. Daarmee kan men zelf bepalen welke gezondheidsdoelen worden nagestreefd, en hoe dergelijke doelen bevorderd kunnen worden in het licht van de waarden en bronnen die individuen en gemeenschappen hebben. Bovendien is het ook wetenschappelijk verantwoord om mensen meer in staat te stellen om die factoren te beheersen. De ervaring leert dat mensen alleen of met hulp van gezondheidsprofessionals- goed in staat zijn om positieve veranderingen in hun milieus en gedrag te bewerkstelligen. Die veranderingen zijn veel substantiëler en duurzamer dan veranderingen die de professionals alleen kunnen realiseren.

Dit ideaal om individuen en gemeenschappen de definitie en determinanten van gezondheid te laten beheersen is echter niet synoniem met het aanreiken van 'volledige controle' over die dimensies van gezondheid. Noch de bevolking, noch professionals geloven immers dat de lekenbevolking exclusiviteit heeft wanneer het gaat om de beperkte mate waarin we bewust de determinanten van gezondheid zouden kunnen beheersen. De algemeen geldende mening is dat iedereen er beter van wordt wanneer de unieke rol van het publiek wordt ondersteund en aangevuld door inspanningen van professionals die opgeleid zijn om over gezondheid na te denken en daar adequaat voor te handelen. Met andere woorden, het publiek en professionals moeten op een of andere manier samenwerken om gezondheidsdoelen vast te stellen en die manieren vast te stellen waarop die doelen het best bereikt kunnen worden. Dit proefschrift is een poging om te bepalen in welke mate het publiek een rol heeft, zou moeten hebben en kan hebben op het terrein van het structureren van dergelijk gezondheidsprofessionalisme.

Overheidsbeleid is het terrein waarop gezondheidsprofessionalisme in grote overmaat vorm krijgt. Het doel van het hier gepresenteerde onderzoek is om na te denken over vigerende ideeën onder het publiek over gezondheid en gezondheidsetiologie in relatie tot de vormgeving van gezondheidsprofessionalisme. Dit proefschrift richt zich daarom allereerst op de vraag naar meningen van de bevolking ten aanzien van overheidsbeleid en gezondheid. Het is echter belangrijk om, teneinde die laatste vraag te beantwoorden, eerst inzicht te krijgen in de genoemde ideeën onder het publiek over gezondheid en gezondheidsetiologie. Zo'n inzicht vergt een helder theoretisch raamwerk waarin de relevantie van het publieke idee over gezondheid en gezondheidsetiologie wordt geconceptu- 
aliseerd. In dat theoretisch kader moet dan ook aan bod komen hoe dat idee spoort met de doelen en middelen van gezondheidsprofessionals. Daarom begint dit proefschrift met de ontwikkeling van dat theoretische kader en gaat verder met het vastleggen van het publieke idee over gezondheid en gezondheidsetiologie. Het proefschrift eindigt met reflecties op de relevantie van het publieke idee over gezondheid ten aanzien van overheidsbeleid en de vormgeving van gezondheidsprofessionalisme.

Hoofdstuk 1 stelt allereerst dat wetenschappelijke, theoretische en praktische inzichten aantonen dat het positivistische beeld van gezondheidsprofessionalisme zijn beperkingen kent. Er wordt een vocabulaire ontwikkeld om subjectiviteit op het terrein van gezondheid en gezondheidsprofessionalisme te kunnen bespreken. Deze vocabulaire wordt vervolgens toegepast op het werk van Aaron Antonovsky en René Dubos. Dit leidt tot een model dat gebruikt wordt als een grondslag voor het bepalen van de plaats van de abstracte notie 'gezondheid' in de meer concrete waarden van gezondheidsetiologische bronnen. Tenslotte wordt in dit hoofdstuk het werk van Jürgen Habermas gebruikt om de dynamiek te conceptualiseren die bestaat om consensus te bereiken tussen het publiek en gezondheidsprofessionals over gezondheidsdoelen en de middelen die men inzet om die doelen te bereiken.

In Hoofdstuk 2 wordt geprobeerd om een natuurwetenschappelijke fundering te vinden voor de constatering dat participatie noodzakelijk is voor het optimaliseren van gezondheid. Het hoofdstuk presenteert eerst een thermodynamisch model voor gezondheid en salutogenese, en stelt vervolgens vast dat Antonovsky's werk kan worden beschouwd als een 'complexity model' van gezondheidsetiologie. Vervolgens wordt aangetoond, door een uitgebreide review van publicaties op het terrein van de salutogenese, dat dit 'complexity model' een verband legt tussen gezondheidsetiologie en de noodzaak van participatie. Dat verband wordt gelegd doordat Antonovsky's model bewijst dat veelen misschien zelfs de meeste-factoren die relevant zijn voor gezondheidstoestand ten dele of uitsluitend beheerst kunnen worden door mensen zélf. Deze constatering leidt tot een slotparagraaf die een beschouwing biedt hoe professionals participatie kunnen ondersteunen door het begrip van het publiek over gezondheid te onderzoeken en stimuleren. Ook wordt aangegeven dat professionals een rol hebben in het onderzoeken en ondersteunen van de capaciteiten die het publiek heeft om die factoren te beheersen.

De Hoofdstukken 3 en 4 zijn de weerslag van een kwalitatief onderzoek onder 103 bewoners van Maastricht. Dat onderzoek beschouwde de meningen van de respondenten over al hetgeen hun gezondheid bepaalt. Het voornaamste doel van het onderzoek was om een zo breed mogelijke inventarisatie te maken van wat mensen als determinanten van gezondheid zien. Een belangrijke vraagstelling was ook of de respons verschilde tussen een open en gesloten vragenlijst 
(om zo te bepalen of een theoretisch gefundeerde, gesloten, vraag iets anders zou opleveren dan een brede vraag naar gezondheid). Daarnaast is bekeken of de data aangaven dat er sociale variaties in de onderzoeksgroep bestonden. In hoofdstuk drie wordt de geaggregeerde inventarisatie gepresenteerd. Ook wordt daar een analyse gegeven van de verschillen tussen open en gesloten vragen. In hoofdstuk vier wordt sociale variatie geanalyseerd op het terrein van de bevindingen ten aanzien van geslacht, leeftijd, gemiddeld buurtinkomen (als een benadering van sociaal-economische status) en rookgedrag. De gegevens in deze hoofdstukken vormen de basis voor de kwantitatieve studie die in Hoofdstuk 6 beschreven wordt.

In Hoofdstuk 5 wordt een inhoudsanalyse gegeven van de vijf grootste Nederlandse dagbladen. Het hoofddoel van die analyse was om te bepalen hoe determinanten van gezondheid in de pers worden afgeschilderd. Men kan de pers (in deze dissertatie beschouwd als een representatie van de massamedia in haar algemeenheid) beschouwen als een essentiële vorm van communicatie tussen beleidsactoren en het publiek. Er bestaat echter een overvloed aan wetenschappelijk werk dat de presentatie van determinanten van gezondheid in de pers niet consistent is met hetgeen gezondheidsprofessionals aan het publiek willen overbrengen. Daarnaast bestaan er inzichten dat de pers niet altijd de meest relevante doelen en middelen van gezondheidsprofessionalisme aan hun publiek voorschotelt, noch dat de pers mensen ertoe stimuleert om onafhankelijk van professionals aan de bevordering van hun gezondheid te werken. Het onderzoek dat hier wordt weergegeven toetst deze inzichten in de Nederlandse context, en ziet ze voornamelijk bevestigd.

Hoofdstuk 6 biedt een omvangrijke kwantitatieve survey van de Nederlandse bevolking over de vraag wat zij vindt dat gezondheid is en bepaalt. Het doel van dit onderzoek was om de inzichten uit hoofdstukken drie en vier kwantitatief te toetsen. De data uit de studie werden gebruikt om een LISREL model te construeren $(n=772)$ waarin de conceptualisering van salutogenetische gezondheidsetiologie van de Nederlanders gerelateerd wordt aan gezondheidsconceptualisering zelf, alsmede aan de mate van vertrouwen die de Nederlanders hebben in verschillende vormen van professionele gezondheidsbevordering. Deze meningen worden bovendien in het model gerelateerd aan sociaal-demografische karakteristieken van de steekproef. De bevindingen geven aan dat de Nederlanders een positief gezondheidsbegrip evenzeer waarderen als een klinische definitie. Ze schrijven een hoge mate van belang toe aan determinanten van gezondheid die individueel beïnvloedbaar zijn, en hebben meer vertrouwen in gezondheidszorg-interventies dan in strategieën op het terrein van de openbare gezondheid ('public health'). In de studie werd aangetoond dat meningen over gezondheid, gezondheidsdeterminanten en professionele strategieën duidelijk variëren op basis van een verschil in geslacht, leeftijd en tussen wel of niet-rokenden. Echter, er werden geen verschillen in de meningen van respondenten 
gevonden op basis van sociaal-economische status. Tenslotte kon hard worden gemaakt dat de mate van overeenstemming van respondenten met een bepaalde gezondheidsdefinitie sterk samenhangt met de toeschrijving van ervaren belang van verschillende typen gezondheidsdeterminanten. De bevindingen uit dit hoofdstuk worden gebruikt in hoofdstuk zeven, waarin bekeken wordt in hoeverre de inhoud van het Nederlandse gezondheidsbeleid overeen stemt met de ideeën van de Nederlandse bevolking.

In Hoofdstuk 7 wordt een onderzoek beschreven rond de compatibiliteit tussen gezondheidsbeleid en de aannames van Nederlanders over de meest geschikte gezondheids-gerelateerde doeleinden en middelen voor gezondheidsprofessionalisme. Beleidsdocumenten die sinds 1985 als meest invloedrijk voor het Nederlandse gezondheidsbeleid worden beschouwd werden geïdentificeerd met een Delphi-methode. Hun inhoud werd geanalyseerd om te kijken hoe gezondheid en gezondheidsdeterminanten worden beschouwd. De resultaten van die analyse worden vergeleken met de bevindingen uit hoofdstuk zes. Deze vergelijking werden tenslotte besproken met zeventien belangrijke actoren met aantoonbare beleidservaring om de betekenis van de gevonden overeenkomsten en verschillen te kunnen verklaren. Die verklaringen richten zich zowel op de huidige status quo, als op de toekomst van het Nederlandse gezondheidsbeleid. Er werden veel overeenkomsten en verschillen gevonden. Het publiek hechtte duidelijk minder belang aan determinanten die minder door het individu te beïnvloeden zijn, waaronder verscheidene sociale determinanten.

Beleidsmedewerkers schreven wel meer belang toe aan dat soort determinanten, hetgeen wellicht ook evenwichter is. De gesprekken met de beleidsdeskundigen toonden vooral aan dat men vindt dat de Nederlandse bevolking een matige doch gevarieerde daadwerkelijke en potentiele invloed heeft op het bepalen van gezondheidsbeleid. De daadwerkelijke invloed op de concrete vorm van dat beleid in de praktijk is echter beperkt.

Hoofdstuk 8, tenslotte, vat de empirische bevindingen van dit proefschrift samen. Dat gebeurt in de terminologie die gelanceerd is in de hoofdstukken een en twee. In dit laatste hoofdstuk wordt verder gebouwd aan een theoretische grondslag voor participatie van de bevolking in de vormgeving van gezondheidsprofessionalisme langs de weg van bijdragen aan beleidsvorming. De empirie toont aan dat er zowel kansen als beperkingen zijn voor de participatie van het publiek in het stellen van gezondheidsdoelen en de middelen die gezondheidsprofessionals hebben om die doelen te verwerkelijken. Deze kansen en beperkingen krijgen nader vorm in een theoretisch kader dat ook intercultureel generaliseerbaar is, en waarmee participatie van het publiek in de formulering en implementatie van overheidsbeleid wenselijk en mogelijk is. 